\title{
A morphological analysis of Japanese crania \\ by means of the vestibular coordinate system
}

\author{
Gen Suwa \\ Department of Anthropology \\ Faculty of Science \\ The University of Tokyo
}

\begin{abstract}
A total of 63 macerated Japanese crania of known sex were analyzed in terms of three dimensional coordinates of 36 landmarks in the vestibular coordinate system. The horizontal plane is defined by the plane of the lateral semicircular canals. The same data were analyzed in both cartesian coordinates $(X, Y, Z)$ and in polar coordinates $(R, T, Z)$. In order to summarize the intra-populational variation, principal component analysis was performed on the correlation matrix of the coordinates. The first principal component accounting for over $30 \%$ of the total variance was interpreted as mainly expressing variance of facial orientation in relation to the vestibular horizontal. Comparison between the Japanese and European whites showed that while the occipital region was almost identical, orientation of the facial skeleton differed markedly in the two populations; the Japanese possessing a more antero-superiorly orientated facial skeleton in relation to the vestibular horizontal. The stability of the occipital region was a feature again confirmed when comparing 10 reference lines in various populations.
\end{abstract}

\section{INTRODUCTION}

Morphological analyses of the human cranium utilizing a reference plane which has direct relationships with head posture would be of great value to disciplines concerned with human evolution. The Frankfort horizontal is the most widely used in this respect. However, it is the opinion of the present author that the Frankfort horizontal has received undue attention. Criticisms have been made from both theoretical and technical viewpoints (Suwa, 1980; Suw A, 1981). An alternative, the vestibular orientation, was

Article No. 8017 applied in the present study. This orientation is determined by the plane of the lateral semicircular canals of the internal ear and has been recommended mainly for its physiological significance (FENART, 1966). Although direct associations of the vestibular orientation with head posture remains to be established, a morphological analysis utilizing this orientation should prove to be interesting. In the present study, a three dimensional space, i.e. the vestibular coordinate system, was defined by the plane of the lateral semicircular canals and the median sagittal plane. The aim of the present study is to describe the Japanese cranium by means 
of this coordinate system in both intraand inter-populational levels. This study is a continuation of a previous study which discussed the fundamental characteristics of the vestibular coordinate system (Suw A, 1981 ); and morphological analyses are based on the data obtained in the previous study.

\section{MATERIALS AND METHODS}

A total of 63 macerated modern Japanese crania were selected of which 40 were male and 23 were female. All male crania and most female crania are of known age between the range from 20 to 44 years. Crania with marked alveolar resorption or any apparent pathological or traumal conditions were not included.

Craniometric data were analyzed in terms of three dimensional coordinates of 36 landmarks chosen to cover all regions of the cranium. Definitions of the landmarks and a detailed explanation of the procedure taken to obtain the coordinate data is presented in the previous study (see SuwA, 1981). The vestibular coordinate system is defined as follows. The $\mathrm{X}$-axis, the anteroposterior axis, is determined by the plane of the lateral semicircular canals and lies in the median sagittal plane. The $Z$-axis, the vertical axis, also lies in the median sagittal plane and is perpendicular to the $\mathrm{X}$-axis. The $\mathrm{Z}$-axis is perpendicular to the former two, thus being the transverse axis. The point vestibion (defined as the middle of the lateral semicircular canals projected onto the sagittal plane) is the origin. $\mathrm{X}$ and $\mathrm{Y}$ coordinates were transformed into polar coordinates ( $R$ and $T$ ) which were also analyzed. The polar coordinates were defined as $R$, the distance from the origin and $\mathrm{T}$, the amplitude.

The advantage of coordinate data is that, as Benfer (1975) and MCHenry and CoRruccini (1978) state, three dimensional coordinates contain all the information available from the landmarks, thus by far exceeding the amount of information available from a limited set of measurements between the landmarks. LAITMAN et al (1978) also discuss the advantages of coordinates. In the present study, no standardization was performed on the coordinate data, although MCHENRY and Corruccini(1978)and Laitman et al (1978) recommend various standardization techniques. The main purpose of standardization is to mute size differences among the samples, which in the present study is not of importance.

\section{PRINCIPAL COMPONENT ANALYSIS}

To summarize the intra-populational variation, principal component analysis was performed on the correlation matrix of the larger male sample. Both cartesian and polar coordinates were analyzed, enabling a more reliable interpretation than could be possible solely from either one. The two sets of coordinates tended to compensate for each other during interpretation. Not all $108(36 \times 3)$ variables were analyzed. Since asymmetry was not of concern, the $Z$ coordinate of the median landmarks were omitted. Thus a total of 90 variables were analyzed.

15 components with eigenvalues greater 
Table 1. Correlation coefficients between principal components obtained from analysis on cartesian and polar coordinates.

\begin{tabular}{|c|c|c|c|c|c|c|c|c|}
\hline & CARTI & SIAN & & & & & & \\
\hline & P C1 & P C2 & P C3 & $\mathrm{PC} 4$ & P C5 & $\mathrm{PC} 6$ & P C7 & $\mathrm{PC} 8$ \\
\hline P C 1 & -0.993 & 0.109 & & & & & & \\
\hline $\mathrm{PC} 2$ & -0.104 & -0.973 & & & & & & \\
\hline $\mathrm{PC} 3$ & & & 0.964 & -0.237 & & & & \\
\hline P C 4 & & & 0.233 & 0.899 & 0.285 & & 0.165 & \\
\hline P C 5 & & & & -0.301 & 0.764 & 0.515 & 0.101 & 0.128 \\
\hline P C 6 & & & & & 0.530 & -0.823 & & \\
\hline P C 7 & & & & -0.133 & -0.122 & -0.170 & 0.890 & 0.331 \\
\hline PC 8 & & & & & & & 0.360 & -0.876 \\
\hline PC 9 & & & & & & & & \\
\hline P C 10 & & & & & & & & 0.103 \\
\hline P C11 & & & & & & & & -0.183 \\
\hline P C12 & & & & & & & & \\
\hline P C13 & & & & & & & & \\
\hline P C14 & & & & & & & & \\
\hline P C15 & & & & & & & & -0.142 \\
\hline P C16 & & & & & & & & \\
\hline & CARTES & $\mathrm{AN}$ & & & & & & \\
\hline & P C 9 & P C10 & P C11 & & C12 & $\mathrm{P} \mathrm{C13}$ & P C14 & P C15 \\
\hline P C 1 & & & & & & & & \\
\hline $\mathrm{PC} 2$ & & & & & & & & \\
\hline P C 3 & & & & & & & & \\
\hline P C 4 & & & & & & & & \\
\hline P C 5 & & & & & & & & \\
\hline $\mathrm{PC} 6$ & & & & & & & & \\
\hline P C 7 & & & & & -0.101 & & & \\
\hline PC 8 & & & 0.162 & & 0.173 & & & \\
\hline P C 9 & 0.916 & -0.211 & -0.130 & & 0.182 & 0.135 & & \\
\hline P C10 & 0.226 & 0.852 & 0.302 & & -0.126 & 0.180 & 0.163 & \\
\hline P C11 & 0.149 & & -0.181 & & -0.745 & -0.352 & 0.234 & 0.207 \\
\hline P C12 & 0.217 & & 0.547 & & -0.113 & -0.526 & -0.459 & -0.237 \\
\hline P C13 & & 0.341 & -0.476 & & 0.386 & -0.549 & -0.179 & \\
\hline P C14 & & & -0.235 & & -0.297 & 0.407 & -0.787 & 0.103 \\
\hline P C15 & & 0.194 & -0.404 & & -0.191 & & & -0.657 \\
\hline P C16 & & 0.123 & -0.139 & & 0.113 & & & 0.533 \\
\hline
\end{tabular}

Only coefficients with absolute values greater than 0.1 are given.

than 1.0 were identified in the analysis nates $(R, T, Z)$. They accounted for $90.6 \%$ on cartesian coordinates $(\mathrm{X}, \mathrm{Y}, \mathrm{Z})$ and 16 and $90.4 \%$ of the total variance in the components with eigenvalues greater than analysis on cartesian and polar coordi1.0 were identified for the polar coordi- nates respectively. Before describing the 
components, the relative stability of the components was tested. Since the cartesian and polar coordinates essentially contain the same information, the extracted components are theoretically expected to coincide. From the factor scores of the individual crania, correlation coefficients between the components obtained from the cartesian and polar coordinates were calculated (Table 1). For the first 10 components, the corresponding components from the two analyses correlated well, whereas from the 11 th to 16 th component the situation was complicated and corresponding components could not be found on a one to one basis. Thus, it can be concluded that only the first 10 components were stable. Therefore, descriptions were made only on these first 10 components. They accounted for $83.3 \%$ and $81.3 \%$ of the total variance in ana- lysis on cartesian and polar coordinates respectively.

The popular varimax rotation was not performed. Rotation is usually carried out to faciliate interpretation of factors whereas principal component analysis is a method of data transformation (KoucHI, 1977). Furthermore, results of varimax rotation were found to differ depending on the number of principal components rotated. As it can be seen in Table 2, from factor 6 onwards, the varimax rotated factors of the first 10 principal components (found to be stable) and that of the first 15 principal components (eigenvalues greater than 1.0) cannot be paired on a one to one basis. This makes interpretations somewhat subtle and less significant.

Subsequent results are of the principal component analysis without varimax ro-

Table 2. Correlation coefficients between varimax rotated factors of 10 and 15 principal components of analysis on cartesian coordinates.

\begin{tabular}{|c|c|c|c|c|c|c|c|c|c|c|}
\hline & $\mathrm{F} \mathrm{C} 1$ & F C2 & F C3 & $\mathrm{F} \mathrm{C} 4$ & F C5 & $\mathrm{F} \mathrm{C} 6$ & F C7 & F C 8 & $\mathrm{FC} 9$ & F C 10 \\
\hline F C 1 & 0.990 & & & & & & & & & \\
\hline F C 2 & & 0.986 & & & & & & & & \\
\hline F C 3 & & & 0.878 & & & & 0.105 & -0.180 & & \\
\hline F C 4 & & & & 0.910 & & 0.120 & 0.136 & & -0.122 & \\
\hline F C 5 & & & & & 0.854 & & -0.119 & & 0.284 & \\
\hline F C 6 & & & & -0.288 & 0.280 & 0.657 & 0.159 & -0.324 & -0.337 & \\
\hline F C 7 & & & & & 0.186 & & 0.533 & 0.603 & & \\
\hline F C 8 & & & & & -0.102 & 0.132 & -0.168 & 0.586 & & \\
\hline F C 9 & & & & & 0.182 & -0.191 & & -0.102 & -0.324 & 0.728 \\
\hline F C 10 & & & & & 0.167 & & -0.122 & & 0.506 & \\
\hline F C11 & & & 0.226 & & 0.154 & & 0.306 & & -0.351 & \\
\hline F C12 & & & -0.294 & & -0.115 & & 0.663 & -0.238 & 0.421 & \\
\hline F C13 & & & & 0.168 & & 0.672 & -0.173 & 0.216 & 0.198 & \\
\hline F C14 & & & 0.241 & -0.180 & -0.131 & 0.153 & 0.156 & 0.168 & 0.228 & 0.632 \\
\hline F C15 & & & 0.102 & & 0.168 & & & & -0.135 & -0.188 \\
\hline
\end{tabular}

Only coefficients with absolute values greater than 0.1 are given. 
tation. The factor matrix of both cartesian and polar coordinates are given in the Appendix. Descriptions are based on the analysis on cartesian coordinates unless indicated otherwise.

PC 1 Facial orientation 38.2\% (XYZ), $30.5 \%$ (RTZ)

All landmarks seem to be rotated in the same direction and substantial loadings were not found in the $Z$ coordinates. As was pointed out by the present author (SuwA, 1981), the vestibular coordinate system seemed to possess a relatively great rotatory variance which was expressed by the high variability of the coordinate T. PC 1 could be considered as an expression of this rotatory variance. However, scrutiny of the loadings shows that more than mere rotatory variance is summarized in this component. This is evident from the fact that the loadings of the $T$ coordinates are not of the same magnitude in all landmarks and from the high loadings on the $R$ coordinates of the anterior facial landmarks. This component could be considered to represent an association of upper facial protrusion with an antero-superiorly orientated facial skeleton relative to the posterior cranium and to the vestibular horizontal.

PC 2 Upper facial protrusion 11.2\% (XYZ), 14.4\% (RTZ)

This component indicates an association of a relatively small face, especially a retracted upper facial region, with a high positioned lower temporal region as represented by $\mathrm{PO}$ and CDL.

PC 3 Postero-inferior skull protrusion 9.0\% (XYZ), 8.7\% (RTZ)
A general postero-inferior dislocation of the occipital bone is associated with a broad face.

PC 4 Cranial breadth 6.5\% (XYZ),6.8\% (RTZ)

A broad cranial vault is associated with a high positioned posterior basicranium. High loadings were also found on the $R$ coordinates of LB, BR, IN and AST indicating some associations with general vault size.

PC 5 Nasal breadth 4.7\% (XYZ), 5.7\% (RTZ)

Highest loadings were found on the $Z$ coordinates of NAR, EK, EM and LG. Associated with a broad face were a high positioned posterior cranial base and a high vault in relation to the anterior cranial base. Analysis on the polar coordinates produced somewhat different results. Loadings of the $\mathrm{R}$ and $\mathrm{T}$ coordinates of the landmarks on the vault were exagerated while concerning the $Z$ coordinates of landmarks on the facial skeleton only NAR had a relatively high loading.

PC 6 Posterior facial breadth $4.0 \%$ (XYZ), 4.5\% (RTZ)

No substantial loading was found in the $\mathrm{X}$ and $\mathrm{Y}$ or $\mathrm{R}$ and $\mathrm{T}$ coordinates. High negative loadings were found in the $Z$ coordinates of LG, CDL, PO and EM and to a lesser extent on AST, ZG, NAR and GO. In the analysis on polar coordinates, loadings were highest on LG, EM, NAR, CDL and PO. This implies that nasopharyngeal breadth might be the major cause of this component.

PC 7 Interorbital breadth $3.0 \%$ (XYZ), 


\section{4\% (RTZ)}

Highest loadings were found in the $Z$ coordinates of $\mathrm{MF}$ and $\mathrm{CP}$, implying associations of small interorbital breadth with relatively posteriorly diverging occipital condyles.

PC 8 Parallelness of occipital condyles 2.5\% (XYZ), 2.7\% (RTZ)

A high negative loading was found in the $Z$ coordinate of CP. Associations with an anteriorly situated foramen magnum and posteriorly placed IN and AST were indicated.

PC 9 Euryon and asterion position 2.2\% (XYZ), 2.0\% (RTZ)

A low positioned EU and a high positioned AST were associated with an antero-superiorly situated $\mathrm{HO}$ and $\mathrm{SE}$ and laterally placed occipital condyles.

PC 10 Gonion position 1.9\%(XYZ), 2.0\% (RTZ)

A high, medially positioned GO was found to be associated with relatively parallel occipital condyles. High loadings on PO found in the cartesian coordinates were not found in the polar coordinates.

\section{Discussions}

Theoretically, the vestibular coordinates contain all morphological and positional information which could be expressed by the landmarks. Information on morphology which could be expressed by simple indices or angles popular in anthropology (cranial, facial, orbital indices, facial angle etc.) are included in the coordinate data. In addition to these regional morphological information, the vestibular coordinates are expected to contain positional information of the different skull regions. Therefore, associations between regional morphology and positional relationships were hoped to be revealed. Although this was realized to some extent, the results were not totally satisfactory. The morphological information being expressed by coordinates was sometimes difficult to detect. For example, PC 9 has high loadings on the $X$ and $\mathrm{Y}$ coordinates of $\mathrm{HO}$ with no substantial loading on PNS and PHT. It can be assumed that this is an expression of pharyngeal shape. However, the present author would feel far assured to have investigated the angle PNS-HO-PHT itself. Similar conditions were found in almost all components.

Another problem is that many aspects of morphology were not identified. No component expressing orbital shape, prognathism, etc. were obtained. This might have occurred in part by difficulty in detecting them as discussed above. However, there are possibilities that information concerning variables commonly used in anthropology were engulfed in the total information. A thorough comparison of coordinate data with ordinary linear and angular variables is desired. After results of such comparisons are obtained, a more detailed interpretation on regional morphology from coordinate data should be possible.

\section{SEXUAL DIFFERENCES}

\section{Sexual difference in the mean}

Mean and standard deviation values of males and females have already been 
Morphology of Japanese crania

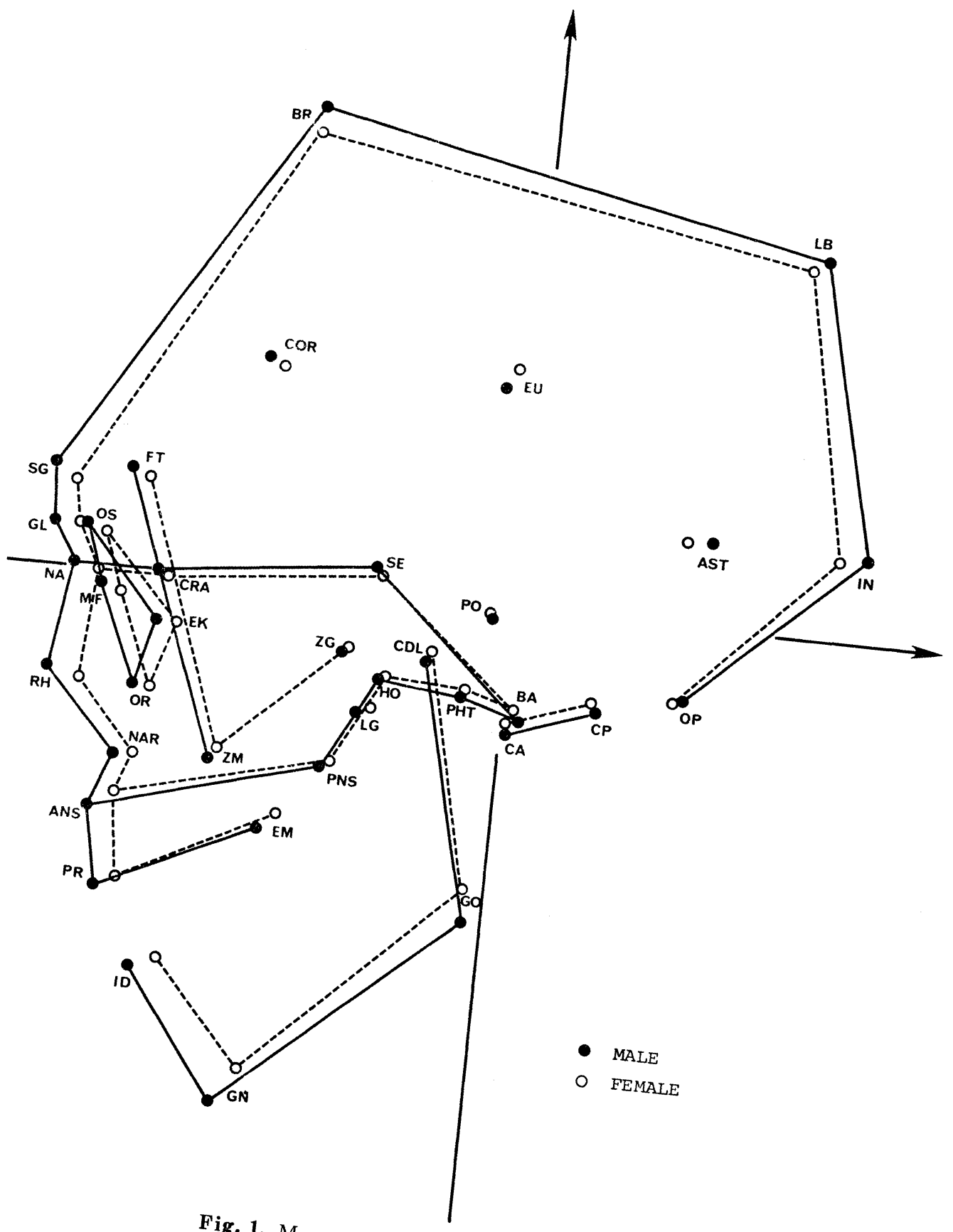

Fig. 1. Mean male and female diagrams. 


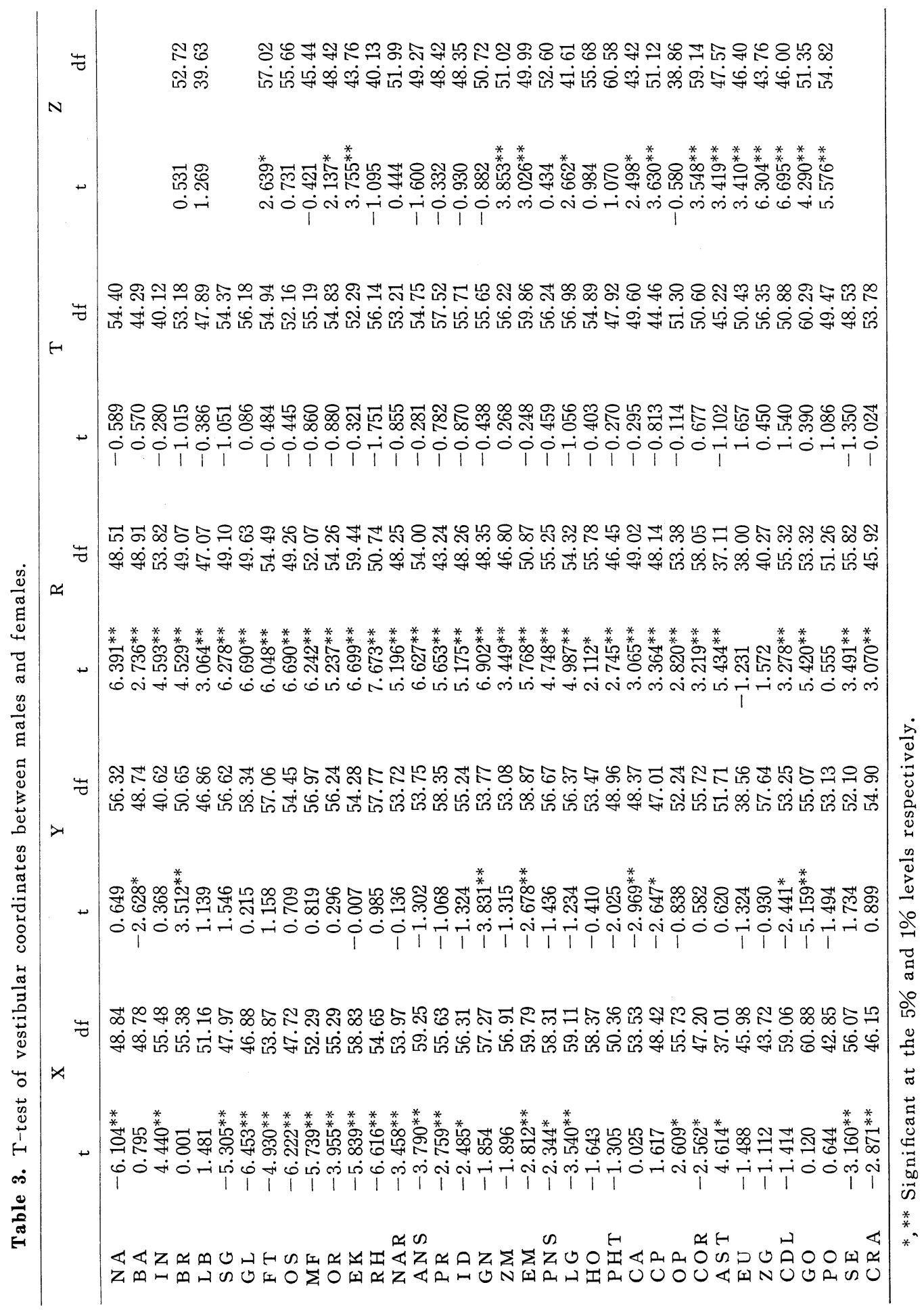


published (Suwa, 1981). Sexual differences were analyzed statistically by $t-$ tests. The value $\mathrm{t}$ was calculated from the formula $\mathrm{t}=(\overline{\mathrm{m}}-\overline{\mathrm{f}}) / \sqrt{\mathrm{s}_{m}^{2} / \mathrm{n}_{m}+\mathrm{s}_{f}^{2} / \mathrm{n}_{f}}$, where $\overline{\mathrm{m}}, \overline{\mathrm{f}}$ are the means, $\mathrm{s}_{m}$, $\mathrm{s}_{f}$ the standard deviations and $\mathrm{n}_{m}, \mathrm{n}_{f}$ the sample sizes of males and females respectively. The degree of freedom is obtained from the formula $\left(\frac{\mathrm{s}_{m}^{2}}{\mathrm{n}_{m}}+\frac{\mathrm{s}_{f}^{2}}{\mathrm{n}_{f}}\right) / \mathrm{df}=\frac{\mathrm{s}_{m}^{4} / \mathrm{n}_{m}^{2}}{\mathrm{n}_{m}-1}+\frac{\mathrm{s}_{f}^{4} / \mathrm{n}_{f}}{\mathrm{n}_{f}-1}$. Table 3 shows the results of t-tests of $\mathrm{X}, \mathrm{Y}, \mathrm{R}$, Tand $Z$ coordinates. The $Z$ coordinates of all landmarks except for $\mathrm{MF}$ and NAR showed significant differences. Most landmarks differed significantly in either X or Y coordinate. The total effect can be demonstrated by superimposing male and female sagittal diagrams (Fig. 1). It can be seen that sexual differences are mainly of size.

Polar coordinates were useful in expressing this situation. The $\mathrm{R}$ coordinates of all landmarks except for EU, $Z G$ and $P O$ have highly significant positive $t$ values. On the other hand, no significant $t$ value was found whatsoever for the $T$ coordinates (Table 3 ). This can be interpreted as sexual difference occurring mainly in size and not in the mutual positioning of the landmarks. Of course minor positional differences do exist. For example the $\mathrm{R}$ coordinate of EU has a negative value. Considered together with the $\mathrm{X}$ and $\mathrm{Y}$ coordinates, it can be seen that EU is positioned higher and more posteriorly in females.

\section{Inclination of the Frankfort horizontal}

The Frankfort horizontal is inclined antero-inferiorly by $15.54^{\circ}$ in males and by $17.42^{\circ}$ in females. Thus, the Frankfort horizontal has a more antero-inferior inclination in females by approximately $1.9^{\circ}$. This sexual difference can be interpreted as a result of the general size difference between males and females, which concerning the upper facial region acts mainly in a horizontal direction.

\section{POPULATIONAL COMPARISONS}

Pellerin (1979) published cartesian coordinates in the vestibular coordinate system of 38 landmarks obtained from 54 Japanese crania from Kobe of Hyogo prefecture. Of the 38 landmarks, 20 are in common with the landmarks selected for the present study. However, PELLERIN's sample are of unknown sex making strict comparisons impossible. It can only be pointed out that his data roughly falls in between the male and female data of the present study, thus reinforcing the present study.

Difference between Japanese and European white crania

Coordinate data of three European white populations from northern France have been published. However, the population studied by CANAL (1978) is a Gallo-Romanian population of a different historical age from the others and the population studied by FENART (1967) consisted of elder individuals. FENART et al (1975) discussed the influence of aging which was summarized as a sinking of the prevestibular region. Furthermore, in these two populations sex was not distinguished, thus discouraging statistical compari- 


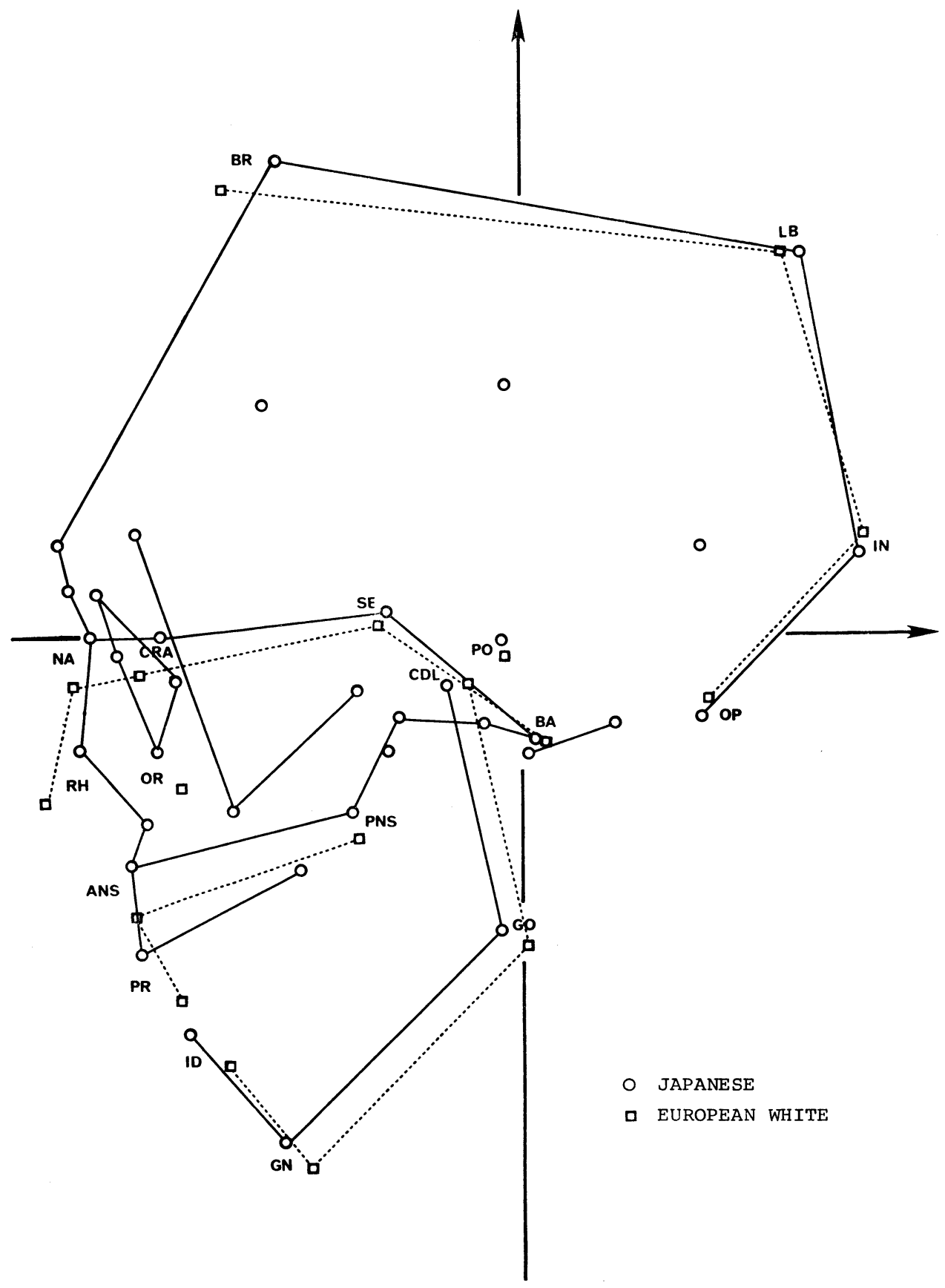

a

Fig. 2. Comparison of Japanese and European white; a, male; b, female. 


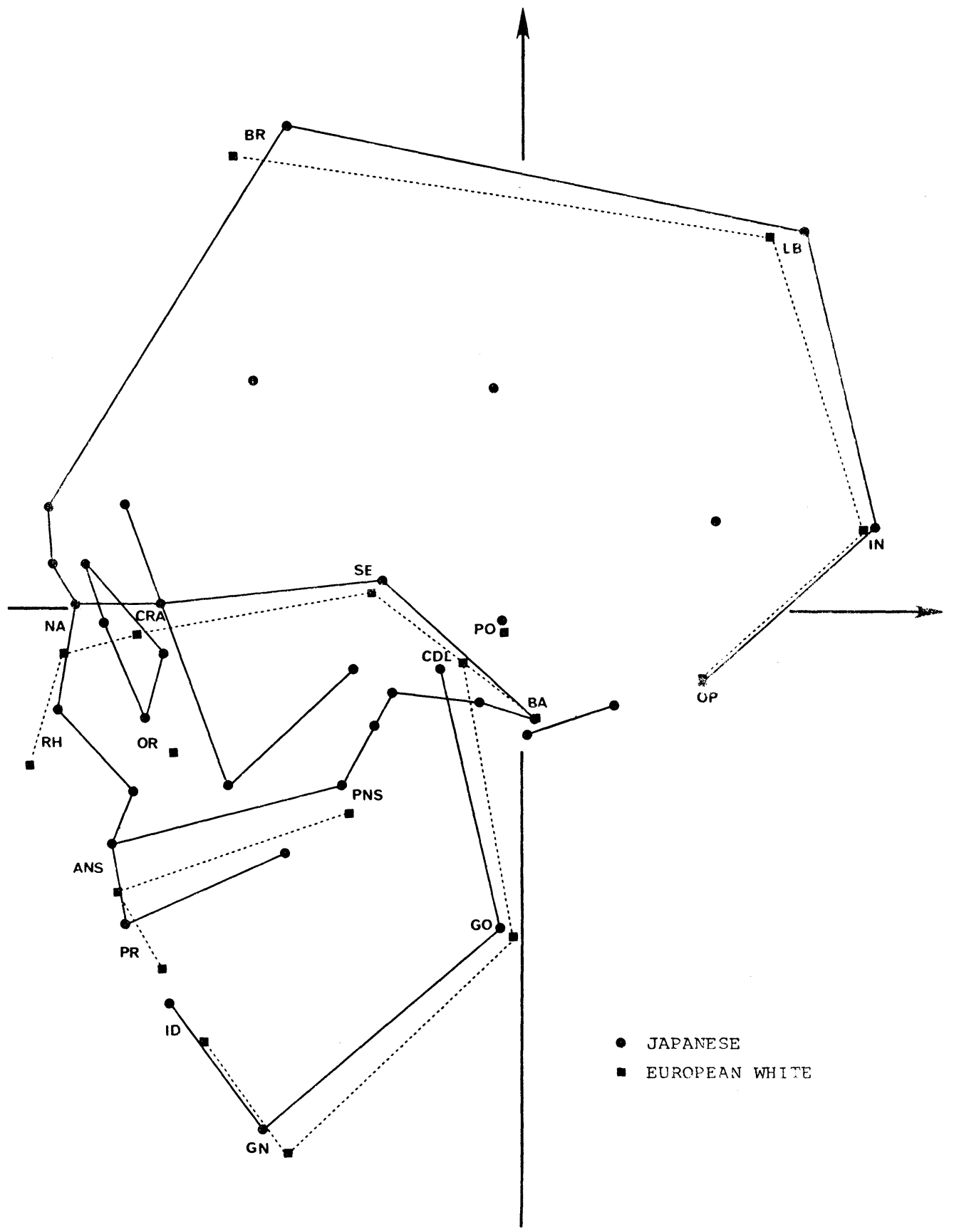

b 
sons. The final French population of Fenart and Salmon (1973) consists of French living subjects of known age and sex. Therefore, comparisons with the Japanese of the present study were made with the population studied by FENART and SAlmon (1973).* The total effect of European white-Japanese differences in the vestibular coordinate system is illustrated in Fig. 2. The position and orientation of the face differs greatly while the occipital region is almost identical. In the Japanese, the whole facial skeleton and cranial base is orientated antero-superiorly in relation to the occipital region and the vestibular horizontal.

This was confirmed statistically by performing t-tests between the Japanese data of the present study and the data published by Fenart and Salmon (1973). The results are given in Table 4. Essentially identical results were obtained for males and females. $\mathrm{X}$ and $\mathrm{Y}$ coordinates of all landmarks on the occipital (BA, OP, IN and LB) did not differ significantly excepting the $\mathrm{X}$ coordinate of $\mathrm{LB}$ in males. On the other hand, landmarks of the anterior cranial base ( $\mathrm{SE}$ and $\mathrm{CRA}$ ), most landmarks of the facial skeleton and $B R$ differed significantly in both $\mathrm{X}$ and $\mathrm{Y}$ coordinates. The X coordinate of ANS and PNS did not differ significantly in both males and females, indicating a relatively strict supero-inferior dislocation of the

\footnotetext{
* The data published by Fenart and Salmon (1973) were not corrected for enlargement. Therefore, in order to make direct comparisons, all coordinates were multiplied by 0.971 following FENART's instruction.
}

palate between the Japanese and the European whites.

Table 4. T-test between Japanese and European whites.

\begin{tabular}{|c|c|c|c|c|c|}
\hline & & \multicolumn{2}{|l|}{ Male } & \multicolumn{2}{|l|}{ Female } \\
\hline & & $\mathrm{t}$ & $\mathrm{df}$ & $\mathrm{t}$ & df \\
\hline \multirow[t]{2}{*}{ B A } & $\mathrm{x}$ & -0.200 & 59.42 & -1.914 & 35.19 \\
\hline & $\mathrm{Y}$ & -0.266 & 61.19 & 0.280 & 3.08 \\
\hline \multirow[t]{2}{*}{$\mathrm{OP}$} & $\mathrm{x}$ & -0.139 & 66.96 & -2.019 & 38.00 \\
\hline & $\mathrm{Y}$ & -1.012 & 70.32 & -1.091 & 38.92 \\
\hline \multirow[t]{2}{*}{ I $\mathrm{N}$} & $\mathrm{x}$ & 1.386 & 67.69 & -0.483 & 3.47 \\
\hline & $\mathrm{Y}$ & 0.229 & 66.88 & -1.513 & 39.97 \\
\hline \multirow[t]{2}{*}{ L B } & $\mathrm{x}$ & $3.703^{* *}$ & 67.27 & 1.528 & 39.04 \\
\hline & $\mathrm{Y}$ & 0.303 & 69.74 & 0.333 & 38.25 \\
\hline \multirow[t]{2}{*}{ B R } & $\mathrm{X}$ & $5.640^{\text {** }}$ & 69.67 & $4.638^{* *}$ & 38.56 \\
\hline & $\mathrm{Y}$ & $4.257^{* *}$ & 65.89 & $3.320^{* *}$ & 37.99 \\
\hline \multirow[t]{2}{*}{ N A } & $\mathrm{x}$ & $3.813^{* *}$ & 64.17 & $2.618^{*}$ & 33.62 \\
\hline & $\mathrm{Y}$ & $6.092^{* *}$ & 70.25 & $5.014^{* *}$ & 39.31 \\
\hline \multirow[t]{2}{*}{ O R } & $\mathrm{x}$ & $-5.855^{* *}$ & 70.97 & $-4.558^{* *}$ & 33.76 \\
\hline & Y & $5.117^{* *}$ & 70.35 & $4.310^{* *}$ & 39.19 \\
\hline \multirow[t]{2}{*}{ R H } & $\mathrm{x}$ & $5.610^{* *}$ & 65.28 & $4.458^{* * *}$ & 31.25 \\
\hline & $\mathrm{Y}$ & $5.910^{* *}$ & 69.84 & $4.592^{* * *}$ & 35.50 \\
\hline \multirow[t]{2}{*}{ ANS } & $\mathrm{x}$ & -0.231 & 70.58 & -0.422 & 31.52 \\
\hline & $\mathrm{Y}$ & $5.700^{* *}$ & 69.36 & $4.259^{* *}$ & 35.65 \\
\hline \multirow[t]{2}{*}{ P R } & $\mathrm{x}$ & $-4.465^{* *}$ & 68.97 & $-3.928^{* *}$ & 39.17 \\
\hline & Y & $5.916^{* *}$ & 69.31 & $5.028^{* *}$ & 38.37 \\
\hline \multirow[t]{2}{*}{ I D } & $\mathrm{x}$ & $-3.898^{* *}$ & 66.88 & $-3.599 * *$ & 35.11 \\
\hline & Y & $5.031^{* *}$ & 70.06 & $3.440^{* *}$ & 39.87 \\
\hline \multirow[t]{2}{*}{ GN } & $\mathrm{X}$ & $-2.142^{*}$ & 62.10 & -1.753 & 32.82 \\
\hline & $\mathrm{Y}$ & $3.588^{* *}$ & 70.71 & $3.099 * *$ & 39.97 \\
\hline \multirow[t]{2}{*}{ P N S } & $\mathrm{x}$ & -1.566 & 69.01 & -1.439 & 33.49 \\
\hline & $\mathrm{Y}$ & $5.992^{* *}$ & 70.81 & $5.704^{* *}$ & 39.00 \\
\hline \multirow[t]{2}{*}{ G O } & $\mathrm{x}$ & $-2.691^{* *}$ & 61.91 & $-2.651^{*}$ & 28.26 \\
\hline & $\mathrm{Y}$ & $2.232^{*}$ & 67.62 & $2.546^{*}$ & 39.37 \\
\hline \multirow[t]{2}{*}{$\mathrm{PO}$} & $\mathrm{x}$ & -0.197 & 70.91 & -1.374 & 32.21 \\
\hline & $\mathrm{Y}$ & $4.597^{* *}$ & 52.24 & $5.175^{* *}$ & 28.53 \\
\hline \multirow[t]{2}{*}{$\mathrm{SE}$} & $\mathrm{X}$ & $2.856^{* *}$ & 57.36 & $2.063^{*}$ & 30.51 \\
\hline & $\mathrm{Y}$ & $3.346^{* *}$ & 66.32 & $2.839^{* *}$ & 37.05 \\
\hline \multirow[t]{2}{*}{ C R A } & $\mathrm{X}$ & $6.051^{* *}$ & 58.54 & $4.180^{* *}$ & 35.83 \\
\hline & $\mathrm{Y}$ & $4.670^{* *}$ & 70.99 & $4.059^{* *}$ & 36.89 \\
\hline
\end{tabular}

*,** Significant at the $5 \%$ and $1 \%$ levels respectively. 


\section{Correlation with natural head position}

The present author (SUw A, 1980) reported that the angle the Frankfort horizontal makes with the true vertical when the head is orientated in the natural head position differed significantly between Japanese and European or American whites. Compared with European or American whites, the Japanese were found to possess a more antero-superiorly orientated Frankfort horizontal in the magnitude of $5^{\circ}$ to $10^{\circ}$. Interestingly, similar conclusions were reached from the vestibular orientation. The angle the Frankfort horizontal makes with the vestibular horizontal was, in the Japanese crania of the present study, $15.54^{\circ}$ and $17.42^{\circ}$ for males and females respectively. The corresponding values for European whites were $20.62^{\circ}$ and $22.10^{\circ}$ for males and females respectively in the French whites studied by Fenart and Salmon (1973), $20.59^{\circ}$ in the Gallo-Romanian population of CANAL (1978) and $23.86^{\circ}$ in the French population of FENART (1967). This indicates that the Frankfort horizontal is inclined more antero-superiorly in Japanese by approximately $5^{\circ}$ to $8^{\circ}$.

Thus, correlation between natural head position and the vestibular orientation was observed in the populational level. This does not necessarily indicate a strict relationship between the two. However, possibility of the two being controlled by common factors cannot be dismissed.

McCullough(1970) examined the visual field of various human populations. $\mathrm{He}$ found that the visual field of Mongoloids differed significantly from that of Euro- pean or American whites. The visual field of Mongoloids was found to be larger medialwards but more confined superiorly and infero-laterally in relation to the Frankfort horizontal. Here, one is reminded of the case of condylar hypoplasia and palpebral ptosis reported by BJöRK and Kuroda (1968). This patient had a restricted upper visual field and because of this held his head in an extraordinary antero-superiorly directed attitude. The restricted upper visual field in relation to the Frankfort horizontal in Mongoloids could be a possible explanation for the relatively antero-superiorly inclined cranial reference lines in both natural head position and vestibular orientation.

\section{Stability of the occipital region among} various human populations

Comparisons of the Japanese crania with European white crania showed that the occipital region was almost identical in the two populations. In order to confirm the relative stability of the occipital region among various human populations, 10 angles were calculated between the vestibular horizontal and various craniofacial reference lines. For definition of the angles see Fig. 3. From the populational means, cross populational variances were calculated (Table 5 ). It can be seen that the foramen magnum is the most stable. The glabella-inion line, the Frankfort horizontal and the orientation of the palate as expressed by ANS-PNS were also relatively invariable among the populations. On the other hand, the most variable was the orientation of the 
facial profile as represented by NA-PR. Orientation of the other facial reference lines, mandibular base ( $\mathrm{GN}-\mathrm{GO})$, mandibular ramus (GO-CDL) and orbit (OSOR) were all highly variable compared to the orientation of the foramen magnum. Reference lines on the cranial base (NA$\mathrm{SE}, \mathrm{NA}-\mathrm{BA}$ ) were intermediate in variability. From the above considerations, it is concluded that the occipital region is relatively stable among populations. Similar conclusions were reached by Prudon (1975), Canal (1978) and PelLERIN (1979).

A characteristic of the vestibular orientation in relation to head posture is that the vestibular orientation tends to orientate the head so as to express cranialcervical spatial relationships. FENART (1966) and TERK and Fenart (1976) published invaluable experimental data which demonstrate this relationship. They experimentally altered body and head postures of rats by amputating their forelegs. In this way a "super-quadrupedal" condition was enforced. This produced a new postural relationship between the cranium and the axial skeleton. The main consequence on cranial morphology was a postero-superior rotation of the occipital region so that the foramen magnum with the whole cerebellar region rotated postero-superiorly in relation to the vestibular horizontal. This was considered as a direct reaction to the experimentally enforced cranial-cervical spatial relationship. Analogously, the relative stability of the occipital region found in the populational comparisons of the present study 


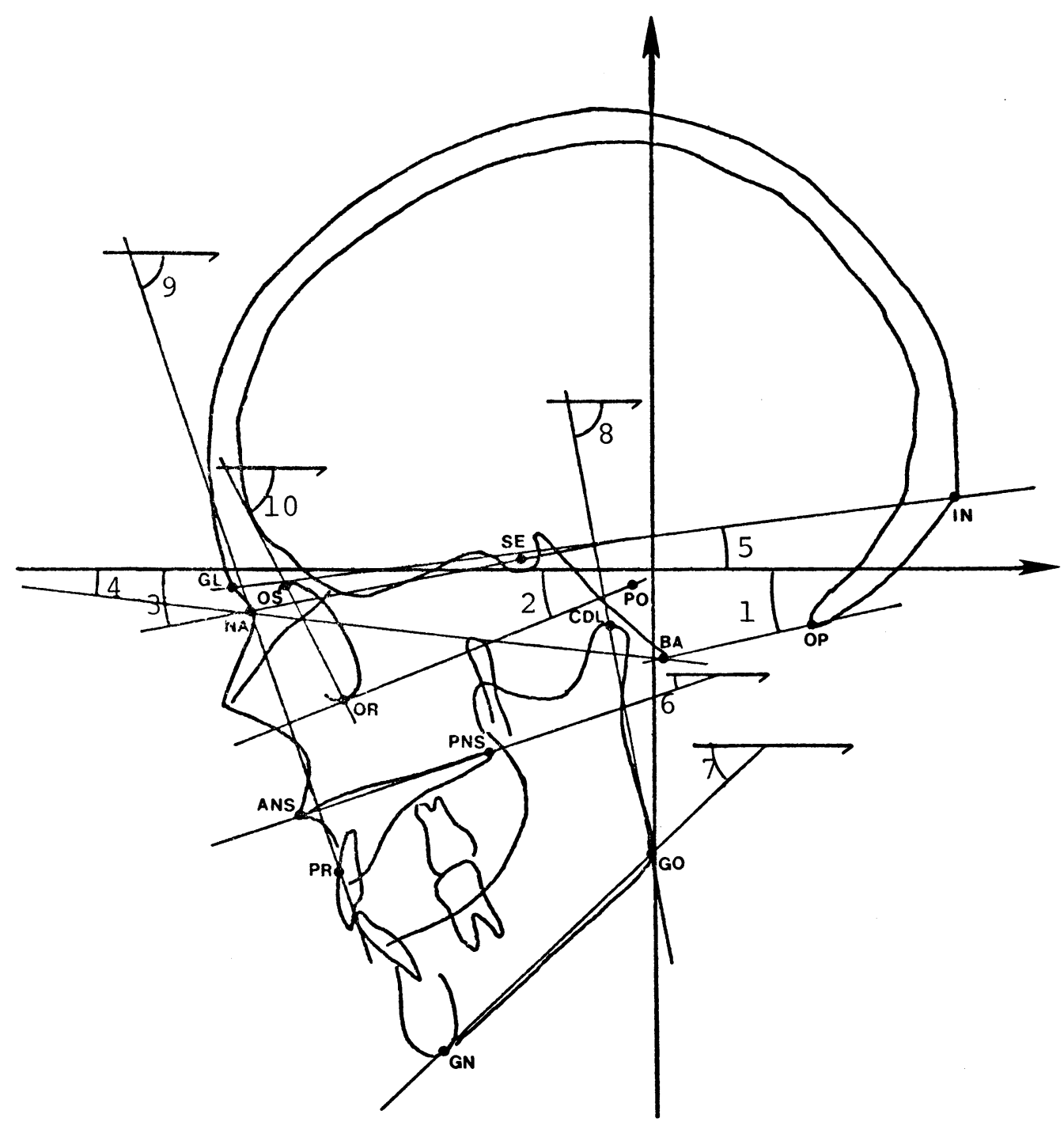

Fig. 3. Explanation of angular measurements,

$1 \mathrm{FOR} / \mathrm{VEST}, 2 \mathrm{FH} / \mathrm{VEST}, 3 \mathrm{NA}-\mathrm{SE} / \mathrm{VEST}, 4 \mathrm{NA}-\mathrm{BA} / \mathrm{VEST}$,

5 GL-IN/VEST, 6 ANS-PNS/VEST, 7 GN-GO/VEST,

$8 \mathrm{GN}-\mathrm{CDL} / \mathrm{VEST}, 9 \mathrm{NA}-\mathrm{PR} / \mathrm{VEST}, 10 \mathrm{OS}-\mathrm{OR} / \mathrm{VEST}$,

(Angles are defined from all landmarks projected onto sagittal plane.)

can be interpreted as expressing a relatively stable cranial-cervical relationship among the populations.

\section{SUMMARY}

The vestibular method was applied to 40 male and 23 female modern Japanese 
crania. The craniometric data were analyzed in terms of three dimensional coordinates of 36 landamrks. Both cartesian coordinates and polar coordinates were analyzed. The two seemed to conpensate for each other during interpretation of the results. In some instances cartesian coordinates were the more useful, and in other instances polar coordinates were the more useful. Results obtained are summarized as follows.

1) Principal component analysis was performed to reveal associations between morphological and positional informations. The 1st principal component accounting for over $30 \%$ of the total variance was interpreted as mainly expressing variance of facial orientation in relation to the vestibular horizontal.

2) Sexual differences were described as being essentially of size difference with little difference in the mutual positioning of the landmarks.

3) Compared with European whites, the Japanese were found to possess a more antero-superiorly orientated facial skeleton in relation to the vestibular horizontal. This result correlates well with differences in facial orientation of the two populations in relation to natural head position in the living.

4) The occipital region of European whites and Japanese was found to be almost identical in the vestibular orientation. This stability of the occipital region was again confirmed in a comparison of various human populations.

\section{ACKNOWLEDGEMENTS}

The author would like to express his deepest and sincere gratitude to Professor K. Hanihara and Associate Professor B. ENDO of the Department of Anthropology, Faculty of Science, The University of Tokyo, for their guidance and continuing interest throughout the present study. The author is especially indebted to Dr. ENDo who has provided invaluable suggestions from the initial planning of this study to the final preparation of the manuscript. Thanks are also expressed to Dr. H. Hoshi of the Department of Anatomy, Faculty of Medecine, The University of Tokyo, for kindly giving permission of studying the Japanese crania.

\section{REFERENCES}

Benfer, R. A.,1975: Morphometric analysis of cartesian coordinates of the human skull. Am. J. Phys. Anthrop., 42: 371-382.

BJÖRK, A. and T. KURODA, 1968: Congenital bilateral hypoplasia of the mandibular condyles associated with congenital bilateral palpebral ptosis. Am. J. Orthodont., 54: 584600.

Canal, P., 1978: Analyse cranio-faciale d'une population de Gallo-Romains en orientation vestibulaire. Th. Dr. en Sc. Odont.

FENART, R.,1966: Influence des modifications expérimentales et tératologiques de la station et de la locomotion, sur la morphologie céphalique des mammifères quadrupèdes. Etude par la méthode vestibulaire. Arch. d'Anat., d'Histol. et d'Embryol. normales et expérimentales, XLIX.

1967: Situation vestibulaire moyen des principaux éléments des neuro-crâne humain adulte, et étude de leur variabilité. Bull. Mém. Soc. d'Anthrop. de Paris, 12-1: 
335-357.

FEnART, R. and J. P. SAlmon, 1973: Differences sexuales de l'extrémité céphalique humain, sur télé-profiles orientés 'in vivo', par la méthode vestibulaire; comparaison avec celles des anthropomorphes. Bull. Mem. Soc. d'Anthrop. de Paris, 13-10: 197-214.

Fenart, R., R. Deblock and P. Dufresnoy, 1975: Modifications apportées par la sénescence, au profile cranien, en orientation vestibulaire. Bull. Mem Soc. d'Anthrop. de Paris, 13-2: 231-242.

Kouchi, M., 1977: Principal component analysis of somatometric data with special reference to the effect of selection of measurement items. J. Anthrop. Soc. Nippon, 85 : 95-121.

Laitman, J. T., R. C. HeimbuCh and E.S. CRELIN, 1979: The basicranium of fossil hominids as an indicator of their upper respiratory systems. Am. J. Phys. Anthrop., 51:15-34.

McCullough, J.H., 1970: The visual field in man and its evolution as related to facial morphology. Ph. D. Dissertation, University of Colorado.

MCHENRY, H. M. and R.S. CorruCCini, 1978: Analysis of the hominoid os coxae by car- tesian coordinates. Am. J. Phys. Anthrop., 48: 214-226.

Pellerin,C., 1970: Analyse tridimensionelle des éléments cranio-faciaux d'une population Mélanésiens en orientation vestibulaire; comparaison avec le crâne européen. Th. Dr.en Sc. Odont., Paris $n^{\circ} 93$.

Pellerin, Y., 1979: Analyse cranio-faciale d'une population de Japonais en orientation vestibulaire. Th. Dr. en Sc. Odont.

Prudon, R.G., 1979: Crânes péruviens précolombiens " non-déformés", Tome 2: Interprétations statistique des données vestibulaires et comparaisons. Th. Dr. en Sc. Odont., Paris $\mathrm{n}^{\circ} 130$.

SuwA, G., 1980: The somatological significance of the Frankfort horizontal. J. Anthrop. Soc. Nippon, 88: 83-95.

1981: Fundamental characteristics of the vestibular coordinate system in human craniology. J. Anthrop. Soc. Nippon, 89: 303328.

TERK, B. and R. FENART, 1976: Conséquences cranio-faciales de l'amputation des membres anterieures chez le rat. Congres E.O.S.

(Received September 5, 1980)

半規管座標系による日本人頭蓋の形態解析

\author{
諏 訪 元 \\ 東京大学理学部人類学教室
}

人類頭蓋を頭位 (head posture) 亿関連のある基準面を用いて解析することは人類進化を考えるうえで興 味深いことである。従来, このような目的の研究では耳眼水平面が最す頻繁使用されてきた。しかしなが ら, 一方では理論面実践面の双方加ら批判が提起されている（SUWA,1980; SUWA, 1981）。本研究では基準 面として三半規管の外側半規管のなす面 (半規管面) を用いた。ての半規管面は主としてその生理学的意義か ら使用が推奨されているものである（FENART, 1966)。本研究の目的はての半規管面を水平面とする半規管 座標系を用いて日本人頭蓋を集団内集団間の両レベルにおいて解析することである。なお，ての研究は筆者に よる前研究 “人類頭蓋学に㧍ける半規管座標系の基本的性質”の継続研究であり, 同一原データを解析したも のである。

使用標本は現代日本人頭蓋骨63個（男 40 , 女23）であり, 年令は $20 \sim 44$ 才に限定した。半規管座標系は原点 をvestibion（外側半規管の中心を矢状面に投影した点）とし，半規管面と正中矢状面とで定義される。この 半規管座標系に36個の計測点を組み込み, 直交座標系 $(X, Y, Z)$ における座標值を原データとした。また, 直交座標 $(X, Y)$ を矢状面上で極座標 $(R, T)$ に変換し, 極座標系 $(R, T, Z)$ を得た。計測方法および計測 点の定義はすでに詳しく述べてある（SUW A，1981）。 


\section{〔主成分分析〕}

集団内変異を総括する目的で主成分分析を行った。各計測点の座標值は頭蓋各部位の形態に関する情報と各 部位の位置関係に関する情報とを持ち合わせている。従って, 主成分分析によって形態と位置関係の関連性を 見出だすととができる。なお，主成分分析は㨁交座標系 $(X, Y, Z)$ と極座標系 $(R, T, Z)$ との双方で分析を 行った。両座標系のデータには同一の情報が含まれているため, 両分析からは同一の結果を得ることが期待さ れた。実際に双方の分析を比較すると，それぞれの分析の第 1 ～第10主成分は一対一に良く対応する。しかし ながら，第11主成分以後は複雑な様相を呈した（Table 1)。また，しばしば行われる varimax 回転は本研 究では最終的には行わなかった。Varimax 回転によって得られる因子は回転する主成分の数によって微妙に 変化し (Table 2), 即ち因子の解釈は人為的なむのとなる。以上の理由から主成分分析の解釈は回転前の主 成分の内, 第 1 第 10 主成分に限定した。結果は以下の通りである。第 1 主成分, 顔面の方位; 第 2 主成分, 上顔部の突出; 第 3 主成分, 後頭部の後下方への突出; 第 4 主成分, 脳頭蓋幅; 第 5 主成分, 鼻幅; 第 6 主成 分, 顔面後部の幅; 第 7 主成分, 眼窩間幅; 第 8 主成分, 後頭顆の平行性; 第 9 主成分, eurion, asterion $の$ 位置：第10主成分, gonion の位置。

[性差]

直交座標系，極座標系の双方で検定を行った (Table 3)。性差は主として大きさの違いと解釈できる (Fig. 1 参照)。乙の状況を極座標系の分析が良く表している。 R 座標（原点からの距離）ではほとんどすべての計 測点において $1 \%$ レベルで有意差が存在したが，T座標（偏角）では $5 \%$ レベルで有意差のある計測点は存在 しなかった。

〔他集団との比較〕

1）日本人頭蓋とヨーロッパ白人頭蓋との比較双方の平均図を重ね合わせることによっておおよその比 較ができる (Fig. 2)。顔面部の位置および方位は著しく異なるが後頭部はほとんで一致する。日本人頭蓋で は顔面頭蓋全体が後頭部および半規管面に対してより前上方を向いているためである。ての結論は統計学上で あ確認された（Table 4)。なお，日本人と欧米白人とでは自然頭位（natural head position）に対する顔 面部の方位が異なることが筆者によってすでに指摘されている（SUW A, 1980）。ての報告は本研究で得た結果 と良く一致する。これは半規管面と自然頭位との間に集団レベルで関連性が存在することを示唆している。

2）後頭部の安定性前述のごとく日本人頭蓋とヨーロッパ白人頭蓋の後頭部はほとんど一致した。この 集団間における後頭部の安定性をより広範囲にわたる比較で調べた。方法としては, 顔面頭蓋, 脳頭蓋に合計 10本の基準線を設け（Fig. 3)，各集団のこれらの基準線と半規管面のなす角度の平均值加集団間分散を計 算した (Table 5)。その結果, 大後頭孔の傾きが半規管面に対して最も安定していることが確認された。 FENART（1966）および TERK and FENART（1976）はラットを使用した実験で半規管面に対する後頭部 の方位は頭蓋と脊柱および形部との位置関係を直接反映していることを示した。同様の論法をむって本研究の 結果を解釈すると，頭蓋と脊柱および頸部との位置関係に関する集団間における変異は相対的に小さいと結論 できる。 
APPENDIX Factor matrix of first 10 principal components (continued) analysis of cartesian coordinates

\begin{tabular}{|c|c|c|c|c|c|c|c|c|c|c|c|c|c|c|c|}
\hline & \multicolumn{3}{|c|}{ P C 1} & \multicolumn{3}{|c|}{ P C 2} & \multicolumn{3}{|c|}{ PC 3} & \multicolumn{3}{|c|}{ P C 4} & \multicolumn{3}{|c|}{ P C 5} \\
\hline & $\mathrm{X}$ & $\mathrm{Y}$ & $Z$ & $\mathrm{X}$ & $\mathrm{Y}$ & $Z$ & $\mathrm{X}$ & $\mathrm{Y}$ & $Z$ & $\mathrm{X}$ & $\mathrm{Y}$ & Z & $\mathrm{x}$ & $\mathrm{Y}$ & $Z$ \\
\hline NA & -494 & 960 & & 746 & 060 & & 129 & 092 & & 105 & 152 & & -218 & 006 & \\
\hline B A & -734 & -069 & & 008 & 265 & & 260 & -656 & & 183 & 456 & & 255 & 267 & \\
\hline I N & 210 & -384 & & -215 & 024 & & 679 & -375 & & 149 & 069 & & -168 & 337 & \\
\hline B R & 755 & 696 & & 229 & -014 & & 332 & 091 & & 168 & 248 & & -171 & 369 & \\
\hline $\mathrm{L} B$ & 517 & -477 & & 048 & -040 & & 677 & -464 & & 004 & 335 & & -207 & 296 & \\
\hline S G & 083 & 938 & & 813 & 105 & & 258 & 069 & & 093 & 194 & & -227 & 026 & \\
\hline GL & -278 & 951 & & 830 & 072 & & 194 & 061 & & 087 & 156 & & -207 & -058 & \\
\hline $\mathrm{F} \mathrm{T}$ & 274 & 826 & 058 & 555 & 243 & -346 & 327 & 203 & 106 & 179 & 008 & 573 & -240 & 137 & 089 \\
\hline O S & -163 & 950 & 037 & 834 & 127 & -403 & 233 & 123 & 179 & 211 & 114 & 542 & -243 & 005 & -107 \\
\hline MF & -555 & 955 & -023 & 651 & 110 & -190 & 204 & 036 & 497 & 060 & 149 & 254 & -206 & 030 & 313 \\
\hline OR & -764 & 956 & 144 & 490 & 192 & -096 & 063 & 079 & 578 & 144 & 036 & 055 & -072 & 068 & 354 \\
\hline E K & -575 & 926 & -092 & 660 & 220 & -244 & 104 & 139 & 640 & 156 & 026 & 161 & -021 & 117 & 426 \\
\hline $\mathrm{RH}$ & -691 & 959 & & 523 & 046 & & 135 & 028 & & 042 & 158 & & -019 & 025 & \\
\hline NAR & -826 & 955 & 077 & 422 & 146 & 104 & 084 & 029 & 324 & 099 & 134 & -454 & 122 & 011 & 542 \\
\hline AN S & -830 & 942 & & 421 & 180 & & 052 & 019 & & 053 & 157 & & 023 & 008 & \\
\hline P R & -894 & 928 & & 262 & 235 & & 051 & -081 & & -051 & 012 & & 058 & -013 & \\
\hline I $\mathrm{D}$ & -910 & 863 & & 207 & 299 & & 031 & -105 & & 080 & 029 & & 071 & -019 & \\
\hline GN & -911 & 749 & & 075 & 405 & & 006 & -220 & & 067 & -012 & & 087 & -005 & \\
\hline$Z M$ & -816 & 899 & -188 & 337 & 335 & -065 & 050 & 041 & 648 & 093 & -119 & -071 & 096 & 120 & 337 \\
\hline $\mathrm{EM}$ & -838 & 841 & 008 & 339 & 412 & -186 & 086 & -038 & 479 & 125 & -108 & -212 & 035 & 071 & 463 \\
\hline P N S & -885 & 820 & & 233 & 346 & & 032 & -155 & & 110 & 131 & & 032 & 027 & \\
\hline L G & -872 & 760 & -037 & 260 & 401 & -000 & 045 & -183 & 346 & 152 & 165 & -272 & 021 & 145 & 406 \\
\hline $\mathrm{HO}$ & -668 & 691 & & 358 & 281 & & 167 & -347 & & 206 & 337 & & 072 & 145 & \\
\hline PHT & -681 & 304 & & 099 & 259 & & 276 & -638 & & 081 & 478 & & 179 & 242 & \\
\hline $\mathrm{CA}$ & -754 & 152 & -144 & 007 & 274 & 037 & 187 & -637 & -065 & 216 & 199 & 062 & 068 & 326 & 039 \\
\hline $\mathrm{CP}$ & -661 & -416 & 135 & -001 & 297 & 112 & 368 & -554 & 251 & 217 & 187 & -085 & 145 & 316 & -064 \\
\hline $\mathrm{OP}$ & -462 & -476 & & -174 & 023 & & 455 & -618 & & 048 & 187 & & 078 & 355 & \\
\hline COR & 642 & 495 & -031 & 280 & 131 & -481 & 359 & 123 & -036 & 247 & 431 & 715 & -223 & 245 & -133 \\
\hline A S T & 403 & -426 & 115 & -201 & -128 & -140 & 524 & -180 & 147 & 291 & -222 & 553 & -133 & 408 & 124 \\
\hline $\mathrm{EU}$ & 391 & -228 & -073 & 224 & 177 & -232 & 054 & -025 & -292 & 408 & 091 & 722 & -069 & 365 & -077 \\
\hline$Z \mathrm{G}$ & -526 & 779 & 001 & -035 & 274 & -395 & 159 & 172 & 395 & 444 & -204 & 435 & 057 & 293 & 293 \\
\hline CD L & -575 & 439 & 082 & 046 & 580 & -371 & 278 & 091 & 092 & 258 & -380 & 197 & 092 & 417 & 270 \\
\hline GO & -873 & 155 & 230 & 088 & 511 & -115 & 068 & -362 & 471 & 202 & -283 & -106 & 089 & 346 & 229 \\
\hline $\mathrm{PO}$ & -284 & 327 & 101 & 031 & 432 & -372 & 044 & 107 & 072 & 163 & -360 & 484 & -068 & 560 & 172 \\
\hline $\mathrm{SE}$ & 066 & 783 & & 655 & 100 & & 410 & -216 & & 110 & 255 & & 189 & 140 & \\
\hline $\mathrm{CRA}$ & -445 & 927 & & 650 & 072 & & 110 & 017 & & 179 & 177 & & -136 & 071 & \\
\hline
\end{tabular}




\begin{tabular}{|c|c|c|c|c|c|c|c|c|c|c|c|c|c|c|c|}
\hline & \multicolumn{3}{|c|}{ P C 6} & \multicolumn{3}{|c|}{ P C 7} & \multicolumn{3}{|c|}{ PC 8} & \multicolumn{3}{|c|}{ P C 9} & \multicolumn{3}{|c|}{ P C10 } \\
\hline & $\mathrm{X}$ & $\mathrm{Y}$ & $Z$ & $\mathrm{X}$ & $\mathrm{Y}$ & $Z$ & $\mathrm{x}$ & $\mathrm{Y}$ & $Z$ & $\mathrm{X}$ & $\mathrm{Y}$ & $Z$ & $\mathrm{x}$ & $\mathrm{Y}$ & $Z$ \\
\hline NA & -198 & 107 & & 039 & 049 & & 042 & 051 & & 025 & 075 & & 061 & -000 & \\
\hline B A & 188 & -084 & & 130 & -140 & & -212 & -124 & & -176 & -056 & & 144 & -151 & \\
\hline I N & 318 & 330 & & 088 & 218 & & 303 & 163 & & -015 & 274 & & -149 & -250 & \\
\hline B R & 063 & 228 & & -068 & 135 & & 150 & 184 & & -008 & -132 & & 092 & 082 & \\
\hline L B & 141 & 110 & & 035 & 233 & & 102 & 133 & & -127 & -041 & & 112 & -002 & \\
\hline S G & -212 & 050 & & -024 & 017 & & 014 & 061 & & 220 & 066 & & 011 & 049 & \\
\hline G L & -221 & 123 & & 002 & 025 & & 035 & 072 & & 144 & 053 & & 038 & 081 & \\
\hline $\mathrm{FT}$ & 048 & 106 & 237 & -377 & 167 & -343 & -091 & 080 & -128 & 110 & 106 & 029 & -168 & -038 & -342 \\
\hline os & -130 & 081 & 234 & -061 & 015 & -059 & -023 & 080 & 031 & 142 & 064 & 102 & -037 & 061 & -118 \\
\hline MF & -213 & 064 & 131 & 029 & 043 & -470 & 049 & 046 & -201 & 072 & 029 & 084 & -040 & 001 & 304 \\
\hline OR & -065 & 060 & 186 & 052 & -010 & -279 & -024 & 018 & -207 & 027 & 016 & 166 & -083 & -022 & -060 \\
\hline E K & 018 & 100 & 142 & -103 & -046 & -293 & -156 & 020 & -059 & 089 & 042 & 226 & -055 & 001 & 092 \\
\hline $\mathrm{RH}$ & -253 & 050 & & -040 & 030 & & 025 & -038 & & -029 & 024 & & 001 & -012 & \\
\hline NAR & -054 & -017 & -312 & 093 & -062 & -374 & 091 & -000 & 037 & 046 & 067 & -041 & 002 & -035 & 128 \\
\hline ANS & -050 & -023 & & -031 & -054 & & 132 & -097 & & 073 & -022 & & 013 & -029 & \\
\hline P R & 035 & -029 & & -021 & 021 & & 156 & -213 & & 127 & -025 & & 020 & -025 & \\
\hline I D & 101 & -016 & & -029 & -057 & & 093 & -268 & & 126 & -054 & & 069 & -021 & \\
\hline GN & 104 & -021 & & -063 & -026 & & 132 & -358 & & 072 & -013 & & 081 & 037 & \\
\hline$Z M$ & -008 & 050 & -255 & -157 & 040 & -340 & 077 & -059 & 170 & 067 & 023 & -062 & 102 & 036 & -113 \\
\hline EM & -076 & -086 & -443 & -036 & -000 & -084 & 201 & -160 & 208 & 108 & -038 & -039 & 070 & 037 & 011 \\
\hline PNS & 027 & -074 & & 107 & 046 & & 150 & -195 & & -069 & 128 & & -036 & 088 & \\
\hline L G & -012 & -090 & -522 & 126 & 013 & 242 & 009 & 035 & -020 & -115 & 028 & 006 & -097 & 183 & -013 \\
\hline $\mathrm{HO}$ & 198 & 000 & & 172 & 026 & & -005 & 016 & & -348 & 264 & & -007 & -027 & \\
\hline PHT & 368 & -077 & & 154 & 027 & & -349 & 049 & & -002 & 076 & & 121 & -056 & \\
\hline $\mathrm{CA}$ & 369 & -115 & 364 & 099 & -282 & -004 & -259 & 071 & 319 & 015 & -228 & 377 & 182 & -137 & 562 \\
\hline $\mathrm{CP}$ & 178 & 065 & 123 & 317 & -217 & 452 & -094 & 020 & -477 & -032 & -143 & 238 & 018 & -199 & -012 \\
\hline O P & 156 & 225 & & 353 & -008 & & -421 & -151 & & 062 & 110 & & 007 & $7-102$ & \\
\hline COR & 139 & 066 & -123 & -007 & 342 & -140 & 079 & 313 & -065 & -145 & -158 & -154 & -140 & 078 & 137 \\
\hline A S T & 223 & 285 & -375 & -086 & 277 & 288 & 335 & 197 & -065 & -123 & 404 & -285 & -154 & $4-084$ & 089 \\
\hline $\mathrm{EU}$ & 129 & 115 & -259 & 171 & -094 & -023 & 243 & -083 & 082 & -288 & -459 & -033 & -040 & 205 & 299 \\
\hline$z G$ & -135 & 018 & -331 & 055 & 159 & 012 & -132 & 018 & -113 & -013 & -087 & 174 & 131 & 035 & -139 \\
\hline $\mathrm{CDL}$ & 062 & 140 & -580 & -313 & 054 & 256 & -146 & -031 & -064 & -041 & -084 & 248 & 051 & 008 & -096 \\
\hline GO & 084 & 115 & -293 & -075 & -187 & 238 & 200 & 044 & 186 & 107 & -076 & -004 & -058 & $8 \quad 264$ & -265 \\
\hline $\mathrm{PO}$ & 165 & 192 & -617 & -209 & 063 & 178 & -089 & 045 & -094 & 132 & -095 & 148 & $3-476$ & $6-242$ & 024 \\
\hline $\mathrm{SE}$ & 174 & -047 & & 191 & 017 & & -095 & 119 & & -198 & 287 & & -161 & $1 \quad 097$ & \\
\hline C R A & -114 & 071 & & 110 & -000 & & 009 & 121 & & -026 & 141 & & -012 & 012 & \\
\hline
\end{tabular}


analysis of polar coordinates

\begin{tabular}{|c|c|c|c|c|c|c|c|c|c|c|c|c|c|c|c|}
\hline & \multicolumn{3}{|c|}{ P C 1} & \multicolumn{3}{|c|}{$\mathrm{PC} 2$} & \multicolumn{3}{|c|}{ PC 3} & \multicolumn{3}{|c|}{ PC 4} & \multicolumn{3}{|c|}{ P C 5} \\
\hline & $\mathrm{R}$ & $\mathrm{T}$ & Z & $\mathrm{R}$ & $\mathrm{T}$ & Z & $\mathrm{R}$ & $\mathrm{T}$ & $Z$ & $\mathrm{R}$ & $\mathrm{T}$ & $Z$ & $\mathrm{R}$ & $\mathrm{T}$ & $Z$ \\
\hline N A & -579 & 949 & & 628 & 177 & & -146 & -062 & & 023 & -163 & & 330 & 000 & \\
\hline B A & 017 & 761 & & 285 & 002 & & 763 & 020 & & -235 & 290 & & 036 & 227 & \\
\hline I N & -082 & 408 & & 156 & -057 & & 432 & -482 & & 388 & 044 & & 213 & 444 & \\
\hline B R & -186 & 773 & & 113 & 268 & & -303 & -238 & & 359 & -219 & & 643 & 039 & \\
\hline L B & 156 & 537 & & -104 & 079 & & -151 & -642 & & 574 & 085 & & 274 & 160 & \\
\hline S G & -544 & 902 & & 601 & 271 & & -253 & -055 & & 137 & -182 & & 334 & 058 & \\
\hline G L & -568 & 932 & & 642 & 202 & & -210 & -039 & & 061 & -141 & & 311 & 054 & \\
\hline F T & -259 & 782 & -078 & 367 & 388 & 276 & -171 & -235 & -051 & 002 & -109 & 562 & 390 & -134 & -013 \\
\hline O S & -509 & 922 & -066 & 687 & 253 & 358 & -192 & -113 & 028 & -049 & -126 & 565 & 346 & 008 & -176 \\
\hline MF & -557 & 939 & 016 & 594 & 218 & 173 & -245 & -010 & 415 & 017 & -143 & 398 & 306 & 003 & 132 \\
\hline O R & -432 & 954 & -145 & 725 & 199 & 074 & -130 & -074 & 543 & -154 & -032 & 260 & 130 & -054 & 256 \\
\hline E K & -445 & 916 & 074 & 734 & 269 & 253 & -150 & -140 & 569 & -114 & -049 & 397 & 041 & -088 & 287 \\
\hline $\mathrm{R} \mathrm{H}$ & -443 & 960 & & 631 & 100 & & -169 & 020 & & -081 & -144 & & 241 & 004 & \\
\hline NAR & -381 & 963 & -089 & 742 & 113 & -099 & -135 & 006 & 446 & -305 & -054 & -274 & -010 & 084 & 324 \\
\hline ANS & -331 & 965 & & 749 & 096 & & -074 & 021 & & -172 & -071 & & 128 & 064 & \\
\hline P R & -332 & 947 & & 738 & 121 & & -005 & 053 & & 141 & 003 & & -026 & 097 & \\
\hline I D & -051 & 939 & & 724 & 132 & & 149 & 029 & & -051 & 064 & & 021 & 113 & \\
\hline GN & 121 & 910 & & 639 & 163 & & 336 & 010 & & 087 & 083 & & -003 & 123 & \\
\hline$Z M$ & -367 & 945 & 188 & 674 & 185 & 091 & -108 & -039 & 662 & -021 & 080 & 131 & -188 & -038 & 125 \\
\hline EM & -092 & 932 & -026 & 840 & 124 & 159 & -053 & 016 & 518 & 003 & 132 & 037 & 026 & -003 & 199 \\
\hline P N S & -158 & 919 & & 734 & 169 & & 207 & 065 & & -246 & 032 & & 084 & 098 & \\
\hline L G & -410 & 916 & 038 & 648 & 214 & -046 & 157 & 103 & 427 & -271 & 003 & -039 & 006 & 009 & 147 \\
\hline $\mathrm{HO}$ & -313 & 814 & & 563 & 115 & & 174 & 313 & & -413 & -053 & & -148 & 057 & \\
\hline PHT & -041 & 671 & & 390 & 116 & & 660 & 421 & & -440 & 013 & & -151 & 221 & \\
\hline $\mathrm{CA}$ & 182 & 773 & 133 & 292 & 056 & 028 & 662 & 029 & -083 & -044 & 231 & 074 & -091 & 181 & 189 \\
\hline C P & 169 & 743 & -122 & 211 & -151 & -126 & 650 & -256 & 276 & 204 & 282 & 005 & -027 & 267 & 021 \\
\hline $\mathrm{OP}$ & 217 & 590 & & 162 & 013 & & 647 & -508 & & 121 & 193 & & -046 & 355 & \\
\hline $\mathrm{COR}$ & -069 & 570 & -002 & 017 & 279 & 421 & -239 & -121 & -218 & 443 & -507 & 604 & 368 & $3-054$ & -404 \\
\hline $\mathrm{AST}$ & -055 & 437 & -118 & 264 & 120 & 093 & 258 & -210 & 016 & 343 & -118 & 614 & 462 & 538 & -213 \\
\hline E U & 280 & 322 & 055 & -141 & 281 & 181 & -045 & 016 & -446 & 138 & -383 & 557 & 310 & -073 & -382 \\
\hline$Z$ G & -209 & 796 & -020 & 129 & 338 & 312 & -150 & -196 & 297 & -456 & 156 & 551 & -015 & -302 & -128 \\
\hline $\mathrm{CDL}$ & -104 & 556 & -112 & 507 & 502 & 277 & -272 & -063 & 069 & 063 & 284 & 305 & -489 & -390 & -144 \\
\hline GO & 070 & 884 & -235 & 476 & 035 & 050 & 302 & 004 & 489 & 302 & 195 & 131 & -421 & 108 & 069 \\
\hline $\mathrm{PO}$ & 046 & 272 & -127 & 311 & 446 & 279 & -086 & -174 & -007 & 171 & 098 & 501 & -475 & -641 & -336 \\
\hline S E & -206 & 774 & & 557 & 327 & & -440 & 174 & & -165 & -236 & & -176 & -030 & \\
\hline C R A & -521 & 914 & & 566 & 198 & & -114 & 007 & & -074 & -177 & & 234 & $1-025$ & \\
\hline
\end{tabular}




\begin{tabular}{|c|c|c|c|c|c|c|c|c|c|c|c|c|c|c|c|}
\hline & \multicolumn{3}{|c|}{ PC 6} & \multicolumn{3}{|c|}{ P C 7} & \multicolumn{3}{|c|}{ P C 8} & \multicolumn{3}{|c|}{ P C 9} & \multicolumn{3}{|c|}{ P C10 } \\
\hline & $\mathrm{R}$ & $\mathrm{T}$ & $Z$ & $\mathrm{R}$ & $\mathrm{T}$ & $Z$ & $\mathrm{R}$ & $\mathrm{T}$ & $Z$ & $\mathrm{R}$ & $\mathrm{T}$ & $Z$ & $\mathrm{R}$ & $\mathrm{T}$ & $Z$ \\
\hline N A & -006 & 117 & & -148 & -008 & & 110 & 017 & & 093 & -057 & & -075 & -019 & \\
\hline B A & -215 & -032 & & 197 & -086 & & -029 & 299 & & -037 & -176 & & 244 & 004 & \\
\hline I N & -482 & -041 & & 146 & 097 & & -261 & -016 & & 167 & 321 & & -135 & -021 & \\
\hline B R & 140 & 167 & & 144 & 025 & & 046 & 091 & & -108 & 080 & & 040 & -114 & \\
\hline L B & -279 & 174 & & 330 & 057 & & -128 & 006 & & -209 & 101 & & 007 & -147 & \\
\hline S G & -017 & 064 & & -061 & 012 & & 069 & 024 & & -071 & -047 & & -000 & -070 & \\
\hline G L & -077 & 156 & & -098 & -005 & & 092 & 041 & & -033 & -005 & & -052 & -102 & \\
\hline F T & 182 & 090 & -145 & 545 & -104 & -477 & 099 & -011 & -056 & -094 & -044 & 067 & 186 & -010 & -282 \\
\hline os & 034 & 100 & -285 & 008 & 006 & -121 & 064 & 044 & -138 & -044 & -012 & 121 & -015 & -094 & -138 \\
\hline $\mathrm{MF}$ & -025 & 066 & 045 & -167 & 003 & -574 & 115 & 007 & 039 & 009 & -014 & -021 & -004 & 001 & 230 \\
\hline OR & 040 & 026 & 002 & -064 & 042 & -406 & 055 & 006 & 041 & -072 & 020 & 093 & 117 & 007 & -098 \\
\hline E K & 076 & 042 & 084 & 204 & 068 & -386 & -009 & 009 & -019 & -094 & 008 & 135 & 010 & -017 & 120 \\
\hline $\mathrm{RH}$ & -189 & 066 & & -063 & 018 & & 067 & -057 & & 053 & -014 & & -016 & 023 & \\
\hline NAR & -104 & 016 & 583 & -099 & 087 & -285 & 183 & 007 & -104 & -148 & -036 & -067 & 040 & 023 & 043 \\
\hline ANS & -051 & 014 & & 031 & 071 & & 188 & -088 & & -068 & 044 & & 026 & 048 & \\
\hline P R & 014 & 002 & & -015 & 031 & & -025 & -152 & & -245 & 062 & & 068 & 084 & \\
\hline I D & 104 & -029 & & 253 & 032 & & -238 & -116 & & -118 & -080 & & -061 & 100 & \\
\hline $\mathrm{GN}$ & 016 & -021 & & 229 & -019 & & -378 & -134 & & -029 & 029 & & -201 & 117 & \\
\hline $\mathrm{ZM}$ & -096 & 028 & 377 & 167 & -068 & -228 & 112 & -108 & -278 & -110 & -016 & -095 & -207 & 056 & -132 \\
\hline $\mathrm{EM}$ & -167 & -000 & 637 & 019 & 018 & 018 & 022 & -174 & -136 & -139 & 072 & -045 & -121 & 089 & 078 \\
\hline PNS & -017 & -036 & & -121 & 094 & & -161 & -136 & & -131 & -086 & & -003 & -070 & \\
\hline $\mathrm{L}$ G & -092 & -093 & 628 & -148 & 032 & 289 & -042 & 050 & 144 & 114 & -035 & 047 & 003 & -162 & 016 \\
\hline $\mathrm{HO}$ & 186 & -110 & & -069 & 045 & & -123 & 076 & & 190 & -338 & & 148 & -035 & \\
\hline PH T & -029 & -287 & & 013 & -071 & & -192 & 343 & & -116 & -049 & & 108 & 033 & \\
\hline $\mathrm{CA}$ & -295 & -316 & -309 & 213 & -119 & -017 & 173 & 297 & -266 & 157 & -022 & 284 & 319 & 083 & 497 \\
\hline $\mathrm{OP}$ & -230 & -010 & -215 & 301 & -038 & 226 & 233 & 045 & 629 & 069 & -060 & 216 & 216 & -149 & 042 \\
\hline C P & -183 & -016 & & 210 & -077 & & 434 & 223 & & -015 & 181 & & -076 & -066 & \\
\hline COR & 262 & 099 & 048 & 420 & -256 & -218 & -165 & 166 & 042 & -118 & 218 & -149 & 272 & -059 & 075 \\
\hline A S T & -369 & 022 & 296 & 147 & 227 & 235 & -404 & 010 & 165 & 270 & 382 & -310 & -099 & 035 & -026 \\
\hline $\mathrm{EU}$ & 142 & 219 & 168 & -179 & -119 & -049 & 000 & 165 & -058 & -507 & 318 & -095 & 119 & -043 & 308 \\
\hline$Z \mathrm{G}$ & -175 & -063 & 397 & 069 & -129 & -102 & -278 & -013 & 110 & -101 & 027 & 210 & -201 & 051 & -105 \\
\hline $\mathrm{CD} \mathrm{L}$ & -107 & -048 & 584 & 315 & -171 & 212 & -169 & -055 & 154 & 133 & 015 & 355 & -136 & 072 & -066 \\
\hline $\mathrm{PO}$ & -157 & -032 & 291 & 175 & -057 & 250 & 080 & -183 & -077 & 119 & 073 & 177 & -337 & 040 & -376 \\
\hline GO & 004 & -132 & 565 & 230 & -091 & 109 & -030 & 011 & 168 & -117 & 132 & 180 & 130 & 227 & 068 \\
\hline $\mathrm{SE}$ & 180 & -037 & & -055 & -022 & & -119 & 083 & & 225 & -227 & & 318 & $3-090$ & \\
\hline C R A & 050 & 051 & & -127 & 028 & & 057 & 092 & & 049 & -141 & & 044 & $1-041$ & \\
\hline
\end{tabular}

